respiratory failure in bronchiolitis. Pediatr Pulmonol 1986; 2: 307-11.

62 Smith PJ, El Khatib MF, Carlo WA. PEEP does not improve pulmonary mechanics in infants with bronchiolitis. Am Rev Respir Dis 1993; 147: 1295-8.

63 Steinhorn RH, Green TP. Use of extra corporeal membrane oxygenation in the treatment of respiratory syncytial virus bronchiolitis: the national experience, 1983-1988. f Pediatr 1990; 116: 337-42.

64 Mallol J, Sly PD. Effect of chloral hydrate on arterial oxygen saturation in wheezy infants. Pediatr Pulmonol 1988; 5: 96-9.
65 Webb MSC, Martin JA, Cartlidge PHT, Ng YK, Wright NA. Chest physiotherapy in acute bronchiolitis. Arch Dis NA. Chest physiotherapy

66 Reynolds EOR, Cooke CD. The treatment of bronchiolitis. f Pediatr 1963; 63: 1205-7.

67 Groothuis JR, Simoes EAF, Levin MJ, et al. Prophylactic administration of respiratory syncytial virus immunoglob ulin to high risk infants and young children. $N$ Engl f Med 1993; 329: 1524-30.

68 Levin MJ. Treatment and prevention options for respiratory syncytial virus infections. $\mathcal{f}$ Pediatr 1994; 124: S22-7.

\title{
Screening for neuroblastoma - biological characteristics of the tumours
}

Mass screening of 6 month old children for neuroblastoma using urinary catecholamine analyses was started in Japan in 1985. The tumours detected appeared to have a good prognosis and overall mortality from the disease did not fall (see Archivist 1991; 66: 1007). A recent paper (Sachiyo Suita and colleagues, fournal of Pediatric Surgery 1994; 29: 599-603) gives more information about these tumours.

Between 1985 and 1990 in the Kyushu area of Japan there were 199 newly diagnosed cases of neuroblastoma. Ninety four of these had advanced disease (stages III and IV) and are the subject of this paper. Of these 94,18 had been detected through the screening programme and 76 presented clinically.

The tumours detected by mass screening and those detected clinically differed considerably in their biological characteristics. Thus the following favourable features were found in the mass screening group: no $\mathrm{N}$-myc oncogene amplification (14 of 18), favourable histological classification (10 of 10), aneuploid nuclear DNA content (three of three), and S-100 protein positive (three of three). In the non-mass screening group the findings were: no $\mathrm{N}-m y c$ oncogene amplification (30 of 45), favourable histology (four of 15), aneuploid nuclear DNA content (three of 10 ), and S-100 protein positive (11 of 21).

Treatment in the mass screening group was variable but generally less aggressive than in the patients who presented clinically. Nevertheless, there were no deaths in the first group but fewer than a quarter of the second group survived for four years.

There seems no doubt, therefore, that the tumours detected by screening are different and carry a much better prognosis. Whether they would regress without treatment is still uncertain. The authors suggest a treatment approach to these tumours including less aggressive chemotherapy. They do not appear to consider the possibility of abandoning the screening programme. Whether repeated or later screening would be more beneficial is not known. 